\title{
Chronic recurrent multifocal osteomyelitis: a case report
}

\author{
Kronik rekürren multifokal osteomyelit: olgu sunumu
}

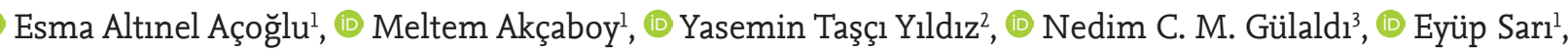 \\ (D) Pelin Zorlu', (D) Saliha Şenel ${ }^{1}$ \\ ${ }^{1}$ Department of Pediatrics, Dr. Sami Ulus Women's and Children's Health Research and Training Hospital, Ankara, Turkey \\ ${ }^{2}$ Department of Radiology, Dr. Sami Ulus Women's and Children's Health Research and Training Hospital, Ankara, Turkey \\ ${ }^{3}$ Department of Nuclear Medicine, Dr. Sami Ulus Women's and Children's Health Research and Training Hospital, Ankara, Turkey
}

Cite this article as: Altınel Açoğlu E, Akçaboy M, Taşçı Ylldız Y, et al. Chronic recurrent multifocal osteomyelitis: a case report. Turk Pediatri Ars 2019; 54(4): 272-6.

\begin{abstract}
Chronic recurrent multifocal osteomyelitis is a rare autoinflammatory, immunologic disorder. It may involve recurrent inflammatory bone pain associated with aseptic osteomyelitis. If the diagnosis is delayed, it negatively influences quality of life by leading to persistent symptoms or joint damage. Herein, we report a 16 -year-old male patient who presented with left hip and right knee pain lasting for the last two months and was diagnosed as having chronic recurrent multifocal osteomyelitis as a result of further evaluation. Improvement was achieved with prednisolone and methotrexate treatment that was initiated when no response to ibuprofen treatment could be obtained. Chronic recurrent multifocal osteomyelitis must be considered in the differential diagnosis in patients presenting with joint symptoms when clinical and radiologic bone lesions are found, no microorganism growth is observed, and no response to antibiotic treatment is obtained.
\end{abstract}

Keywords: Arthralgia, arthritis, chronic recurrent multifocal osteomyelitis.

\section{Öz}

Kronik rekürren multifokal osteomyelit nadir görülen, otoinflamatuvar, immün bozukluktur. Aseptik osteomiyelitle ilişkili tekrarlayan inflamatuvar kemik ağrıları ile seyredebilmektedir. Tanı gecikmesi durumunda persistan bulgulara ya da eklem hasarına neden olarak hayat kalitesini olumsuz etkilemektedir. Burada iki aydır olan sol kalça ve sağ diz ağrısı ile başvuran ve ileri değerlendirme sonucu kronik rekürren multifokal osteomyelit tanısı alan 16 yaşında erkek hasta sunulmuştur. İbuprofen tedavisine yanıt alınamaması üzerine başlanan prednisolon ve metotreksat tedavileri ile iyileşme sağlanmıştır. Eklem yakınmaları ile başvuran hastalarda, klinik ve radyolojik olarak kemik lezyonlarının saptanması halinde, herhangi bir mikroorganizma üretilememesi ve antibiyotik tedavisine yanıt alınamaması durumunda ayırıcı tanıda kronik rekürren multifokal osteomiyelit mutlaka düşünülmelidir.

Anahtar sözcükler: Artralji, artrit, kronik rekürren multifokal osteomyelit

ity being case series. It is thought that most cases are not diagnosed and are followed up as other diagnoses because it is a lesser known morbidity. Therefore, its true prevalence is not known $(1,2)$. Herein, we report an adolescent patient who presented with chronic joint symptoms and was diagnosed as having CRMO in the follow-up. It is important to consider CRMO in the differential diagnosis in the presence of chronic joint symptoms, especially in adolescents. and the mean age of occurrence of the condition is 11 years.

Chronic recurrent multifocal osteomyelitis (CRMO) is a rare autoinflammatory, immunologic disorder. It is clinically manifested by recurrent inflammatory bone pain associated with aseptic osteomyelitis. The female/male ratio is $2 / 1$ Nearly 400 cases of CRMO have been reported, the major- 


\section{Case}

A 16-year-old male patient presented to our center with symptoms of left hip and right knee pain, which had lasted for the last two months. It was learned that his pain increased in the evenings, did not respond to painkillers, and he had difficulty in walking because of pain. His symptoms were not associated with any trauma or infection with fever. The patient's personal and familial history revealed no pathology. A physical examination revealed that he weighed $42 \mathrm{~kg}(<3 \mathrm{p})$, his height was $169 \mathrm{~cm}(25$ $\mathrm{p})$, and he was protecting his left hip joint during gait. It was found that flexion and extension movements in the left hip joint were painful and limited. Examination of the other systems and joints were found to be normal. The laboratory findings were as follows: hemoglobin $(\mathrm{Hb}) 13.6 \mathrm{~g} / \mathrm{dL}$, platelet count $316 \mathrm{000} / \mathrm{mm}^{3}$, white blood cells (WBC) $9400 / \mathrm{mm}^{3}$, peripheral smear normal, C-reactive protein (CRP) $8 \mathrm{mg} / \mathrm{L}$, and erythrocyte sedimentation rate $33 \mathrm{~mm} / \mathrm{h}$. Liver enzymes, renal function tests, serum electrolytes, lactate dehydrogenase (LDH), and complete urinalysis were found to be normal. Viral markers tested in terms of infection were found to be negative. Among the tests performed for rheumatic diseases, human leukocyte antigen B27 (HLA-B27) was found to be positive, and antinuclear antibody (ANA) and anti-double stranded DNA (anti-dsDNA) were found to be negative. Bone marrow examination and ophthalmologic examinations were found to be normal. Abdominal ultrasonography reveal no pathologic findings. In direct bone radiography, sclerosis was observed in bilateral acetabular rooves (Fig. 1). Magnetic resonance imaging (MRI) of the hip region revealed hyperintense signal changes around bilateral femoral intertrochanteric, left iliac bone, and sacroiliac joints, in the acetabular rooves, in the right ischiatic bone and in the inferior pubic ramus in the T2-A6 sequence. Edema in the iliopsoas muscle and external obturator muscle, erosive changes in the anterior part of the right sacroiliac joint, and increased fluid in the right hip, were observed. It was noted that the findings were primarily significant in terms CRMO when pathologies including histiocytosis, leukemia, and lymphoma were excluded. Whole-body scintigraphy revealed increased blood flow and increased activity uptake in static phase in the right femoral trochanter major and in the calcaneal epiphyseal line in the left foot, and increased activity uptake in the static phase in the right superior ramus pubis (Fig. 2, 3a, b). A pathologic examination of the medullar samples obtained from the distal parts of bilateral femurs and left iliac bone revealed predominance of CD3, CD20-positive $T$ and $B$ lymphocytes, and myeloperoxidase (MPO)-positive granulocytes, and S-100 positive histiocytes. A diagnosis of CRMO was made because the pathologic examination

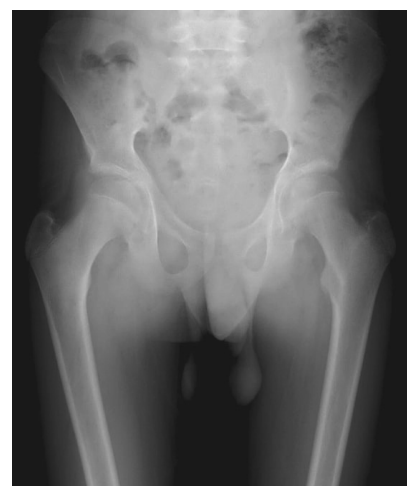

Figure 1. Appearance of sclerosis in bilateral acetabular rooves on hip radigraphy

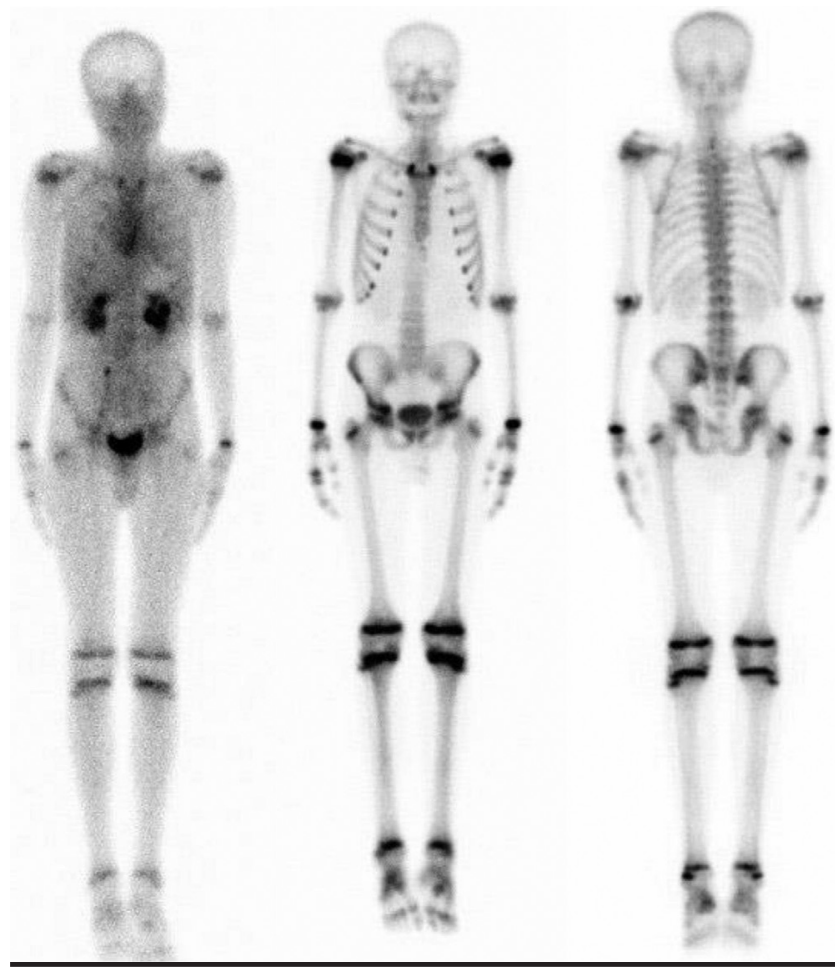

Figure 2. Early screening and static whole-body bone scintigraphy (Tc99m-MDP) (a)

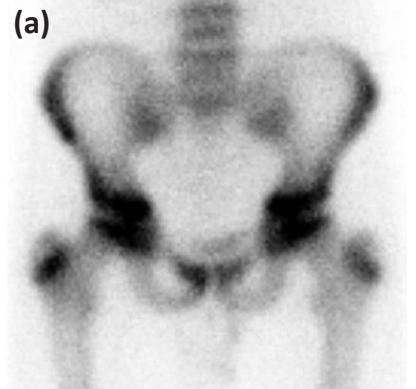

(b)

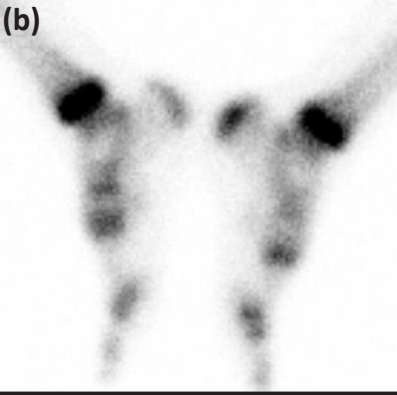

Figure 3. (a) Anterior pelvis static bone scintigraphy. Increased activity uptake compared to its symmetrics in the medial part of the right superior ramus pubis and in the epiphyseal line in the right trochanter major. (b) Lateral static bone scintigraphy of both feet. Increased activity accumulation in the left calcaneal epiphyseal line compared to its symmetrics 
of bone was compatible with osteomyelitis, bone scintigraphy revealed multifocal involvements, and infection and neoplasia were excluded in light of a detailed differential diagnosis obtained for infection and neoplasia by consulting pediatric infectious diseases and pediatric hematology-oncology departments. Ibuprofen treatment, which was initiated because of severe pain in the diagnostic stage, was discontinued after 6 weeks when the diagnosis was confirmed and when no adequate treatment response could be obtained in this period. Prednisolone $(1 \mathrm{mg} / \mathrm{kg} /$ day $)$ and methotrexate $\left(14 \mathrm{mg} / \mathrm{m}^{2} /\right.$ week $)$ treatment was initiated. The dose of prednisolone was tapered when it was found that the patient's symptoms improved completely and acute-phase reactants became negative at the follow-up visit two months later. The patient received prednisolone treatment for a total period of 14 months and methotrexate treatment for a total period of 17 months. His treatment was discontinued when the clinical status improved completely. The patient is still being followed up without any symptoms. Written consent was obtained from the patient's family to share the patient's data in science media.

\section{Discussion}

Chronic recurrent multifocal osteomyelitis (CRMO), which is also known as chronic nonbacterial osteomyelitis, is an autoinflammatory bone disease that primarily affects children and adolescents. It is not associated with any microorganisms, autoantibodies or antigen-specific $T$ cells. Inflammatory markers including CRP, erythrocyte sedimentation rate, interleukin (IL)- 6 and tumor necrosis factor (TNF)- $\alpha$ may increase at the time of recurring episodes. Therefore, most patients are misdiagnosed as having bacterial osteomyelitis, hospitalized for long periods, and receive parenteral antibiotic treatment, and this may cause a delay in diagnosis $(3,4)$. Our patient had a moderate increase in acute-phase reactants and no microorganism could be shown.

There is no specific diagnostic laboratory test for this disease. Lytic lesions and sclerosis found on direct radiography are important findings, but the most sensitive imaging method is MRI. It can show cortical thickening, sclerosis, lytic lesions, and edema in bones, and may be more helpful in the diagnosis, especially in the early phases of the disease in terms of detecting bone edema and asymptomatic bone lesions before osteolysis or sclerosis develops $(5,6)$. In addition, synovial thickening, increased fluid, and cartilage damage may be observed in the joint adjacent to the bone in $30 \%$ of cases (7). Although the metaphyses of long bones and pelvis are involved frequently, the mandibula, veretebrae, and small bones in the hands and feet may also be involved. In the study conducted by Wipff et al., (2) which included the highest number of patients in the literature, the sites of involvement in 178 patients with CRMO were as follows, in order of frequency: lower extremity (47\%), pelvis (16\%), clavicula (10\%), vertebrae (8\%), and mandibula (5\%).

Our patient, who presented with left hip and right knee pain was found to have sclerosis in bilateral acetabular rooves on direct radiography, lytic lesions in the anterior part of the right sacroiliac joint, and minimally increased fluid in the right hip on MRI. Three-phase whole-body scintigraphy performed with Tc99m-MDP revealed increased activity in the right femoral trochanter major, in the calcaneal epiphyseal line in the left foot, and in the medial part of the right superior ramus pubis. These findings were considered to be compatible with recurrent osteomyelitis areas in these regions (Fig. 2, 3a, b). In addition, pathologic examination of the samples obtained from bilateral femurs and left iliac bone supported the considered diagnosis. It has been reported that extraarticular findings including palmoplantar pustulosis, psoriasis, Crohn diseases, and Sweet syndrome might accompany the disease $(2,4)$. Investigations showed that our patient had no additional comorbidities.

The pathophysiology of this disease is not known. According to some points of view, it is classified as the juvenile form of synovitis, acne, pustulosis, hyperostosis, osteitis (SAPHO) syndrome (2). Recent studies have shown that there is an imbalance between proinflammatory (IL6 , TNF- $\alpha$ ) and anti-inflammatory cytokines (IL-10) as a result of a problem in expression of IL-10 in monocytes in patients with CRMO (8). An alternative hypothesis is that CRMO is a disease in the group of spondyloarthritis. A positive HLA-B27 test is found most frequently in juvenile ankylosing spondylitis (80-90\%). HLA-B27 may also be positive in anterior uveitis, enthesitis-related arthritis, psoriatic arthritis, and inflammatory bowel disease-related arthritis with lower frequencies. In addition, 5-6\% of the general population is HLA-B27- positive, and 20-40\% of these individuals may develop ankylosing spondylitis (9). Our patient was also found to be HLA-B27-positive, and HLA-B27 positivity may be observed with a rate of $7 \%$ in CRMO (2). It is thought that different genes may also be involved in development of CRMO because of low rate of positivity, and that the disease may be included in non-HLA-B27 spondyloarthritis (9). Juvenile spondyloarthropathy was excluded and a diagnosis of CRMO was made because enthesitis did not accompany our patients's signs, bone biopsy revealed findings compatible with osteomyelitis, and bone scintigraphy revealed increased activity uptake in the right femoral trochanter 
major, in the calcaneal epiphyseal line in the left foot, and in the medial part of the right superior ramus pubis, which supported multifocal osteomyelitis.

CRMO may also be observed in two different syndromic forms including Majeed syndrome and deficiency of IL-1 receptor antagonist (DIRA). Majeed syndrome is characterized by CRMO with onset before the age of two years and an homozygous LPIN2 mutation accompanied by transfusion-dependent congenital dyserythropoietic anemia. DIRA, which is characterized by the association of perinatal-onset diffuse pustular dermatitis and CRMO, develops as a result of an autosomal recessive ILIRN mutation. However, most patients have the non-syndromic CRMO form and the genetic cause is not known (1, 10, 11). We considered our case to be non-syndromic CRMO because the symptoms began in adolescence, and anemia and skin lesions did not accompany. In one study, the mean time between onset of the first symptom and the time of diagnosis was found as 15 months (3). The causes for delayed diagnosis may include the fact that the disease is lesser known, absence of specific clinical, laboratory, and imaging findings, and difficulty in differentiating inflammation from infection. A diagnosis of CRMO was made in our patient whose symptoms had lasted for the last two months as a result of further examinations performed at the time of the first attack, though he had no symptoms related to the musculoskeletal system in his personal history. Considering CRMO more frequently in patients presenting with pain related to the musculoskeletal system will decrease unnecessary antibiotic use.

Non-steroid antiinflammatory drugs (NSAID) are the first-line drug group to be preferred in the treatment of CRMO, and treatment with these drugs has been shown to be successful in most patients $(12,13)$. In patients who do not respond to NSAID drugs, there is no standard treatment approach as second-line therapy. Corticosteroids, methotrexate, sulfasalazine, bisphosphonates, anti-TNF, and anti-IL-IR (anakinra) are among the drugs used for this objective (2). Further studies and larger case series are needed to develop treatment strategies in this area. Ibuprofen was used as an NSAID in our patient for 6 weeks during the period when other causes including mainly infections and malignancy were excluded and the diagnosis was clarified. Prednisolone and methotrexate treatment were initiated when no response could be obtained to ibuprofen treatment and the diagnosis was clarified, and a marked clinical improvement was provided.

CRMO, which is a disease observed rarely in childhood, influences quality of life negatively by leading to persis- tent symptoms or joint damage in the event of delayed diagnosis. CRMO must be considered in patients presenting with joint symptoms, if clinical and radiologic bone lesions are found, no microorganism can be grown, and no response to antibiotic treatment is obtained.

Informed Consent: Written consent was obtained from the patient's family to share the patient's data in science media.

Peer-review: Externally peer-reviewed.

Author Contributions: Concept - E.A.A., S.Ş.; Design E.A.A., M.A.; Supervision - S.Ş., P.Z.; Data Collection and/ or Processing - Y.T.Y., N.C.M.G., E.S.; Analysis and/or Interpretation - Y.T.Y., N.C.M.G., E.S.; Literature Review Y.T.Y., N.C.M.G., E.S.; Writing - E.A.A., P.Z., M.A.; Critical Review - M.A., S.Ş., P.Z.

Conflict of Interest: No conflict of interest was declared by the authors.

Financial Disclosure: The authors declared that this study has received no financial support.

Hasta Onamı: Aileden hasta bilgilerinin bilimsel ortamda paylaşılması için yazılı izin alınmıştır.

Hakem Değerlendirmesi: Dış bağımsız.

Yazar Katkıları: Fikir - E.A.A., S.Ş.; Tasarım - E.A.A., M.A.; Denetleme - S.Ş., P.Z.; Veri Toplanması ve/veya İşlemesi - Y.T.Y., N.C.M.G., E.S.; Analiz ve/veya Yorum - Y.T.Y., N.C.M.G., E.S.; Literatür Taraması - Y.T.Y., N.C.M.G., E.S.; Yazıyı Yazan - E.A.A., P.Z., M.A.; Eleştirel İnceleme - M.A., S.Ş., P.Z.

Çıkar Çatışması: Yazarlar çıkar çatışması bildirmemişlerdir.

Mali Destek: Yazarlar bu çalışma için mali destek almadıklarını beyan etmişlerdir.

\section{References}

1. Ferguson PJ, Sandu M. Current understanding of the pathogenesis and management of chronic recurrent multifocal osteomyelitis. Curr Rheumatol Rep 2012; 14: 130-41.

2. Wipff J, Costantino F, Lemelle I, et al. A large national cohort of French patients with chronic recurrent multifocal osteitis. Arthritis Rheumatol 2015; 67: 1128-37.

3. Roderick M, Shah R, Rogers V, Finn A, Ramanan A. Chronic recurrent multifocal osteomyelitis (CRMO)-advancing the diagnosis. Pediatr Rheumatol Online J 2016; 14: 47.

4. Borzutzky A, Stern S, Reiff A, et al. Pediatric chronic nonbacterial osteomyelitis. Pediatrics 2012; 130: el190-7.

5. Taddio A, Ferrara G, Insalaco A, et al. Dealing with 
Chronic Non-Bacterial Osteomyelitis: a practical approach. Pediatric Rheumatology 2017; 15: 87.

6. Moussa T, Bhat V, Kini V, Fathalla BM. Clinical and genetic association, radiological findings and response to biological therapy in seven children from Qatar with non-bacterial osteomyelitis. International journal of rheumatic diseases 2017; 20: 1286-96.

7. Schnabel A, Range U, Hahn G, Siepmann T, Berner R, Hedrich C. Unexpectedly high incidences of chronic non-bacterial as compared to bacterial osteomyelitis in children. Rheumatol Int 2016; 36: 1737-45.

8. Hofmann S, Kubasch A, Ioannidis C, et al. Altered expression of IL-10 family cytokines in monocytes from CRMO patients result in enhanced IL-1 $\beta$ expression and release. Clin Immunol 2015; 161: 300-7.

9. Dougados M, Baeten D. Spondyloarthritis. Lancet 2011;
377: 2127-37.

10. Cox AJ, Darbro BW, Laxer RM, et al. Recessive coding and regulatory mutations in FBLIMl underlie the pathogenesis of chronic recurrent multifocal osteomyelitis (CRMO). PloS one 2017; 12: e0169687.

11. Bader-Meunier B, Van Nieuwenhove E, Breton S, Wouters C. Bone involvement in monogenic autoinflammatory syndromes. Rheumatology (Oxford) 2018; 57: 606-18.

12. Abril JC, Ramirez A. Successful treatment of chronic recurrent multifocal osteomyelitis with indomethacin: a preliminary report of five cases. J Pediatr Orthop 2007; 27: 587-91.

13. Girschick HJ, Zimmer C, Klaus G, Darge K, Dick A, Morbach $\mathrm{H}$. Chronic recurrent multifocal osteomyelitis: what is it and how should it be treated? Nat Clin Practi Rheumatol 2007; 3: 733-8. 